Vol 2. No 2. Agustus 2018

ISSN 2580-5029

\title{
Comparison of DNA Isolation Results using Simple Methods and Kits in Samples of Psidium guajava Leaves
}

\author{
Yuanita Rachmawati1 ${ }^{*}$, Romyun Alvy Khoiriyah' ${ }^{1}$ \\ ${ }^{1}$ Universitas Islam Negeri Sunan Ampel Surabaya \\ *yuanitarhartono@gmail.com
}

\begin{abstract}
DNA isolation is one of a series of methods that must be carried out on the basic techniques of Molecular Biology Analysis. Especially PCR-based molecular marking techniques. Many ways are done in DNA isolation. This study discusses the comparison of the results of DNA isolation using two methods. Simple DNA isolation methods and using Kit. Samples of Psidium guajava leaves used were taken from 15 different locations used. In general, DNA isolation methods include three steps, namely destruction, precipitation, and purification. Simple DNA isolation is done with detergents, alcohol groups, which are commonly available in the laboratory. Methods of DNA isolation with KIT are carried out according to the Promega Universal Wizard KIT protocol. The comparison results are seen from spectrophotometric absorption $\AA 230 \mathrm{~nm}, \AA 260 \mathrm{~nm}, \AA 280 \mathrm{~nm}, \AA 3320 \mathrm{~nm}$, ratio Å260/Å230, ratio Å260/Å280 to see DNA purity, protein concentration before purification step, and DNA concentration produced. The results showed that there were no statistically significant differences in the results of DNA isolate spectrophotometry. However, the use of KIT with modified protocols is more recommended if researchers want to carry out DNA analysis more precisely and accurately.
\end{abstract}

Keywords: DNA isolation, spectrophotometry, DNA concentration and purity

\section{INTRODUCTION}

DNA isolation is a molecular based technique that separates pure DNA from proteins and other cell components. DNA isolation aims to obtain good DNA quality in various uses such as molecular markers, genome library making, and sequencing. However, problems are often found in the plant DNA isolation process, that is found the presence of contaminant compounds in isolated samples such as polysaccharides, polyphenols, proteins, RNA, and secondary metabolites commonly found in medicinal plants (Varma et al., 2007). There are three important steps in DNA isolation: destruction of cell walls (lysis), separation of DNA from other organelles such as (protein, polysaccharides, RNA, and fat), and DNA purification. Optimization of DNA isolation procedures can be carried out with incubation 
temperature and duration that are suitable for obtaining template genomic DNA in molecular analysis (Langga et al., 2012).

DNA isolation methods can be carried out using conventional (simple) methods or modern methods (kits). Simple methods are often used because of limited materials or relatively expensive kit prices. So that the material was modified in the form of kits with other materials that have similar roles. While the method with the use of kits is the use of special liquids for pure DNA isolation (Fitriya et al., 2015). A set of DNA isolation kits generally consists of liquids which each play a role in DNA destruction, precipitation and purification (Jannah, 2014). In several previous studies, the kit method has been proven and tested to be very effective in isolating DNA both in terms of quantity and quality of DNA produced. But there is a lack of use of the isolation method with this KIT, the cost of which is quite expensive (Syafaruddin et al. „, 2011).

\section{METHOD}

The spectrophotometer used is BIODROP, while the DNA Isolation Kit refers to the Promega Universal Wizard Kit protocol.

\section{SIMPLE DNA ISOLATION}

\section{Destruction}

$50 \mathrm{mg}$ of crushed Psidium guajava leaf sample added $300 \mu$ l of detergent buffer (consisting of $240 \mathrm{ml}$ of sterile Aquades, $3 \mathrm{~g}$ of $\mathrm{NaCl}, 10 \mathrm{~g}$ of $\mathrm{NaHCO}_{3}$ and $10 \mathrm{ml}$ of detergent concentration of $33 \%$ ). Transferred to the tube $(1.5 \mathrm{ml})$ and vortex. Centrifuge $\pm 10,000 x g$ for 5 minutes. Supernatant was taken and moved to a new tube. A spectrophotometer to see the protein content.

\section{Precipitation and Purification}

Added by supernatant ratio: isopropyl (1: 2). Centrifuge $15,000 \mathrm{xg}$ for 5 minutes. Washed with $300 \mu \mathrm{l}$ of $70 \%$ ethanol, in vortex. Centrifuge 15,000xg (5 minutes). Pellets are diluted with $100 \mu \mathrm{l}$ TE. Then read by spectrophotometer.

\section{DNA ISOLATION WITH KIT}

\section{Destruction}

$50 \mathrm{mg}$ of crushed sample, plus $300 \mu \mathrm{l}$ of NLS into crushed mortar. Inserted tube $(1.5 \mu \mathrm{l})+300 \mu \mathrm{l}$ of NLS divorced. $65^{\circ} \mathrm{C}-15$ minutes incubation. Added $3 \mu \mathrm{l}$ RNAse solution, suspended. $37^{\circ} \mathrm{C}-15$ minutes incubation, cool the room temperature in 5 minutes.

\section{Rehydration precipitation and DNA}


Added $200 \mu$ l of PPS, vortex, and cooled ice temperature for 5 minutes. Disentrifuge $15000 x g$ for 3 minutes. A spectrophotometer to see the protein content. The new supernatant was removed. Added isopropanol, divortex supernatant removed. Plus $600 \mu$ of $70 \%$ ethanol, then vortexed. Centrifuge of $15000 \mathrm{xg}$ in 1 minute the rest of ethanol is removed, air dried. Plus $100 \mu$ l DRS. Then read by spectrophotometer.

\section{RESULTS AND DISCUSSION}

DNA is a compound that contains genetic information of living things from one generation to the next. The entire DNA in a cell will form the genome. Genomes are part of functional and nonfunctional genes in organism cells (Yuwono, 2008).

DNA isolation can be done simply by breaking cell walls, plasma membranes, and core membranes both mechanically and chemically. Mechanical breakdown of the cell wall can be done by blending or grinding the sample with mortar and pistil, while chemically done by adding detergent solution into the sample to lyse the core membrane, so that it can remove the contents of the cell nucleus containing DNA (Buwono, 2017). Addition of detergent in the DNA isolation process simply causes cell membrane lysis and inhibitors of nuclease enzyme activity. Whereas $\mathrm{NaCl}$ aims to concentrate DNA. This can happen because $\mathrm{Na}^{+}$ions form bonds with phosphate ions (Nugroho, 2017).

The first step is to isolate DNA with the Kit in the same way as the stages of DNA isolation in a simple way. The first stage is the process of destruction or destruction of membranes and cell walls. The breakdown of membranes and cell walls is the initial process of DNA isolation. This process aims to remove cell contents. The stages of destruction of membranes and cell walls in this experiment were carried out physically using mortar. 50 grams of Psidium guajava leaves were given a solution of Nucleic Lysis Solution (NLS) of $600 \mu \mathrm{l}$. The goal of being given an NLS solution is to play a role in lysis of cell membranes which can also play a role in reducing the activity of nucleus enzymes which are DNA degrading enzymes. After that, put it in the minitube and vortex for about 10 seconds to be homogeneous. Then the sample was incubated at $650 \mathrm{o}$ for 15 minutes. Addition of $3 \mu$ RNAse solution to separate RNA so that the DNA produced is truly pure.

The next process is precipitation and purification. The addition of Protein Precipitation Solution (PPS) solution is to 
Biotropic 2018. 2 (2): 93 - 99

Comparison of DNA Isolation Results using Simple Methods and Kits in Samples of Psidium guajava Leaves

precipitate protein or protein homogeneous. Addition of DNA precipitation. PPS is composed of buffer Rehydration Solution (DRS) for drying or salt. 15,000xg centrifuged for 3 minutes evaporation of the solution (Elrod, 2007). to precipitate and produce two phases Then a spectrophotometer is measured. namely supernatant and pellet. The resulting supernatant is then transferred to the new minitube. Then isopropanol was added with the aim to be able to precipitate DNA in the aquoeus phase so that the clumping DNA formed a fiber structure and pellets formed after centrifugation. Purification with ethanol as much as $600 \mu \mathrm{l}$ and in vortex to be
The results of this study are presented in Table 1 . below. Table 1. shows the results of DNA Isolation Spectrophotometry on $\AA 230, \AA 260, \AA$ 280, $\AA$ 320, Ratios on $\AA 260 / \AA 2230$ and $\AA$ 260/A 280, DNA and Protein Concentrations. The data that has been obtained is then analyzed statistically using SAS 9.1 portable version program. 
Table 1. Results of DNA Isolation Spectrophotometry on $\AA 230, \AA 260, \AA 280$, $\AA$ 320, Ratios on $\AA 260$ / 2230 and $\AA 260$ / Å 280, DNA and Protein Concentrations

\begin{tabular}{|c|c|c|c|c|c|c|c|c|c|c|c|c|c|c|c|c|c|}
\hline \multirow[t]{2}{*}{ No } & \multirow[t]{2}{*}{ Sampel } & \multicolumn{2}{|c|}{$\AA ̊ 230$} & \multicolumn{2}{|c|}{$\AA 260$} & \multicolumn{2}{|c|}{ A 280} & \multicolumn{2}{|c|}{$\AA 320$} & \multicolumn{2}{|c|}{$\AA 260 / \AA ̊ 230$} & \multicolumn{2}{|c|}{$\AA 260 / \AA ̊ 280$} & \multicolumn{2}{|c|}{$\begin{array}{c}\text { DNA } \\
\text { Concentration }\end{array}$} & \multicolumn{2}{|c|}{$\begin{array}{c}\text { Protein } \\
\text { Concentration }\end{array}$} \\
\hline & & $\mathrm{S}$ & $\mathrm{K}$ & $\mathrm{S}$ & $\mathrm{K}$ & $\mathrm{S}$ & $\mathrm{K}$ & $\mathrm{S}$ & $\mathrm{K}$ & $\mathrm{S}$ & $\mathrm{K}$ & $\mathrm{S}$ & $\mathrm{K}$ & $\mathrm{S}$ & $\mathrm{K}$ & $\mathrm{S}$ & $\mathrm{K}$ \\
\hline 1. & Location 1 & 0.205 & 0.084 & 0.146 & 0.077 & 0.129 & 0.878 & 0.090 & 0.996 & 0.487 & 0,730 & 1.436 & 1.588 & 2.799 & 0.945 & 264 & 420 \\
\hline 2. & Location 2 & 0.185 & 2.486 & 0.129 & 2.536 & 0.115 & 1.247 & 0.074 & 0.961 & 0.494 & 0.412 & 1.344 & 1.149 & 2.735 & 0.386 & 290 & 1.056 \\
\hline 3. & Location 3 & 0,327 & 0,508 & 0,255 & 0,334 & 0,234 & 0,283 & 0,151 & 0,187 & 0,590 & 0,458 & 1.254 & 1,530 & 5.183 & 7,357 & 1.205 & 266 \\
\hline 4. & Location 4 & 0,222 & 0,305 & 0,143 & 0,235 & 0,138 & 0,206 & 0,083 & 0,139 & 0,433 & 0,456 & 1.090 & 1,430 & 3.016 & 4,823 & 1.150 & 296 \\
\hline 5. & Location 5 & 0,334 & 0,153 & 0,349 & 0,099 & 0,336 & 1,905 & 0,317 & 0,055 & 1,905 & 0,449 & 1,700 & 1,333 & 1.579 & 2.203 & 252 & 328 \\
\hline 6. & Location 6 & 0,001 & 0,255 & 0,049 & 0,172 & 0,050 & 0,153 & 0,054 & 0,104 & 0,095 & 0,450 & 1,234 & 1,388 & 0.264 & 3.396 & 210 & 589 \\
\hline 7. & Location 7 & 1,009 & 0,805 & 0,750 & 0,443 & 0,658 & 0,369 & 0,487 & 0,210 & 0,504 & 0,392 & 1,538 & 1,465 & 13,15 & 11,66 & 267 & 546 \\
\hline 8. & Location 8 & 0,774 & 0,451 & 0,582 & 0,248 & 0,512 & 0,200 & 0,355 & 0,102 & 0,542 & 0,419 & 1,446 & 1,489 & 11,34 & 7,308 & 290 & 678 \\
\hline 9. & Location 9 & 0,327 & 0,474 & 0,255 & 0,307 & 0,234 & 0,270 & 0,151 & 0,176 & 0,590 & 0,440 & 1.260 & 1.393 & 4.124 & 6.552 & 271 & 617 \\
\hline 10. & Location 10 & 0,334 & 1,929 & 0,349 & 1,229 & 0,336 & 1,129 & 0,317 & 0,783 & 1,905 & 0,389 & 1.710 & 1.289 & 9.275 & 22.28 & 284 & 659 \\
\hline 11. & Location 11 & 0.513 & 0.525 & 0.318 & 0.287 & 0.292 & 0.243 & 0.219 & 0.128 & 0.337 & 0.400 & 1.356 & 1.384 & 4.956 & 7.934 & 262 & 635 \\
\hline 12. & Location 12 & 1.142 & 0.481 & 0.761 & 0.357 & 0.659 & 0.316 & 0.474 & 0.229 & 0.430 & 0.509 & 1.552 & 1.469 & 14.34 & 6.417 & 258 & 715 \\
\hline
\end{tabular}

\section{Information:}

S: Isolate in a simple way

K: Isolate with Kit

The unit is expressed in $\mu \mathrm{g} / \mathrm{ml}$ 
DNA ratio values (Sambrook et al., 1989) obtained on $\AA 260$ / $230 \mathrm{~nm}=2$ 2.2, then pure DNA; if $=<2$ then contaminated with chemistry (carbohydrate); if => 2.2, the blank used is not appropriate. For purity values on $\AA$ $260 / \AA 280 \mathrm{~nm}=1.8-2$, pure DNA; if = $<1.8$ then there are protein contaminants; if $=>2$, then there are RNA contaminants. According to Fatchiyah (2011), pure DNA will have a value of $\AA 260$ / $\AA 230$ ranging from 2-2.2. DNA is said to be contaminated by carbohydrates or other chemicals if the value is lower than. If the value is higher than 2.2 , this indicates that the form used does not match the DNA solvent used. DNA contains bases of purines and pyrimidines which can absorb UV light. Double DNA bands can absorb UV light at $260 \mathrm{~nm}$, while protein or phenol contaminants can absorb light at $280 \mathrm{~nm}$. The difference in absorption of UV light can be used to determine the purity of DNA which can be measured by calculating the absorbance value of 260 $\mathrm{nm}$ divided by the absorbance value of 280 ( 260 / ̊̊280).

After table data were analyzed using statistical analysis, the results showed that there were no significant differences between DNA isolation methods in a simple way and using a kit. In this study also obtained the results of DNA purity which is quite low. If the purity value of DNA below the value of 1.8 means that it is still contaminated with protein or phenol in the solution and must be cleaned with proteinase K (Sartika et al., 2010). According to Sulandari and Zein (2003), if the purity value of DNA above 1.8 is then refined by adding RNAse.

This can be made possible by the texture of hard guava leaves which can be separated by debris and DNA using the two methods above. There are still many contaminants such as phenols and other proteins. Problems both occur in the process of destruction, precipitation, and purification. Many factors that cause DNA purity in this lab are still a little low. In addition to being contaminated with chemicals, samples also still have RNA and protein, so the results are not pure DNA.

\section{CONCLUSION}

There is no significant difference between DNA isolation methods in a simple way and using a kit. In the study, the results of DNA purity were quite low. This can be made possible by the texture of hard guava leaves which can be separated by debris and DNA using the two methods above. There are still many contaminants such as phenols and other proteins. Problems both occur in the 
process of destruction, precipitation, and purification.

To isolate DNA from Psidium guajava leaves, it would be better to do a lot of literature studies about the best method to get truly pure DNA. The Promega kit can be used with modifications to get better DNA isolation results.

\section{REFERENCES}

Buwono, I. D. 2017. Buku Ajar Aplikasi Teknologi DNA Rekmbinan untuk Perakitan Konstruksi Vektor Ekspresi Ikan Lele Transgenik. Deepublish, Yogyakarta.

Elrod, S. 2007. Genetika Edisi Keempat. Erlangga, Jakarta.

Fatchiyah, N. F., Estri, L. A., Sri, W., \& Sri, R. 2011. Biologi Molekular. Erlangga, Jakarta.

Langga I. F., Restu, M., \& Tutik, K. 2012. Optimasi Suhu dan Lama Inkubasi dalam Ekstraksi DNA Tanaman Bitti (Vitex cofassus Reinw.) serta Analisis Keragaman Genetik dengan Teknik RAPD-PCR. J. Universitas Hasanuddin. Makassar. 12(3) : 265-267.
Nugroho, E.D. 2017. Pengantar Bioteknologi (Teorii dan Aplikasi). Deepublish, Yogyakarta.

Sahasrabudhe, A. and M. Deodhar. 2010. Standardization of DNA Extraction and Optimization of RAPD-PCR Conditions in Gracinia indica. International Journal of Botany. Vol 6 (3): 293-298. ISSN: 1811-9700.

Sambrook, J., Fritsch, E. F., \& Maniatis, T. 1989. Molecular Cloning. Cold Spring Harbor Press, University of Texas South Western Medical Centre, Texas.

Syafaruddin, E., Randriani, \& Tri, J. S. 2011. Efektivitas dan Efisiensi Teknik Isolasi dan Purifikasi DNA Pada Jambu Mete. Buletin RISTRI. 2(2) : 151-160.

Sulandari, S. dan M. S. A. Zein. 2003. Panduan Praktis Laboratorium DNA. Buku. Edisi pertama. Bidang Zoologi, Puslit Biologi, LIPI.

Varma, A., Padh, H., \& Shrivastava, N. 2007. Plant Genomic DNA Isolation. An art or a science. Biotechnol. J. 2:386-392.

Yuwono, T. 2008. Biologi Molekular. Erlangga, Jakarta. 